\title{
CAN CROP DISEASE CONTROL COPE WITH CLIMATE CHANGE?
}

\author{
Aiming Qi and Bruce D.L. Fitt, School of Life and Medical Sciences, University of Hertfordshire, Hatfield ALIO \\ 9AB, UK. E-mail:a.qi@herts.ac.uk consider the implications of global warming on control of Phoma in oilseed \\ rape and Erysiphe in sugar beet
}

Keywords: Climate change, crop protection, crop diseases and pests, food security, oilseed rape phoma stem canker, Leptosphaeria spp., sugar beet powdery mildew, Erysiphe betae

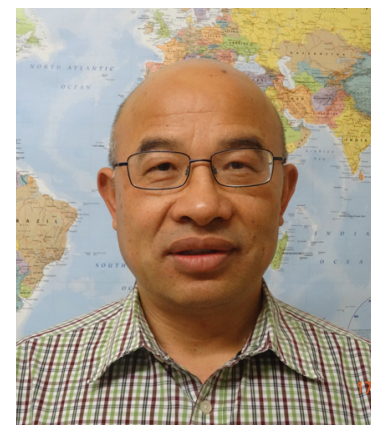

Aiming Qi

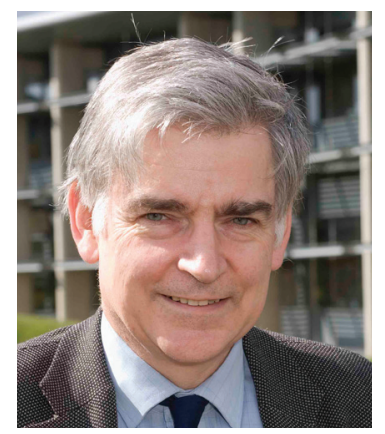

Bruce Fitt

\section{Introduction}

Crop yields need to increase by at least $70 \%$ over the next 35 years in order to meet the global demands for food due to the increasing population and changing dietary preferences towards meat and dairy products in developing nations (Bruinsma, 2011). Climate change threatens food security because pests and diseases that limit crop productivity are all sensitive to climate change and especially to more frequent extreme weather events. A more variable climate will mean greater uncertainty for crop yields because crop development stages, e.g. when reproductive organs such as flowers and seeds are produced, are especially vulnerable to short periods of extreme temperature or drought. For instance, Europe experienced an extreme climate event during the summer of 2003 when temperatures were ca. $6^{\circ} \mathrm{C}$ higher and rainfall was ca. $300 \mathrm{~mm}$ less than the long-term mean values (Tubiello et al., 2007). One impact of this summer was a record crop yield decrease of ca. $36 \%$ below average yield in Italy for maize.

Many studies have been done on impacts of climate change on crop productivity and food security but have most assumed that current crop protection methods will be equally effective, efficient and economically viable under future climate change scenarios. They have often also assumed that better and wider implementation of crop protection technology will decrease losses from pests and diseases and so narrow the yield gap between potential yield and actual farm yield. Few studies have assessed the impacts of climate change on the range and severity of crop disease epidemics (Evans et al., 2008; Butterworth et al., 2010). However, Barnes et al. (2010) pointed out the importance of understanding the impact of climate change

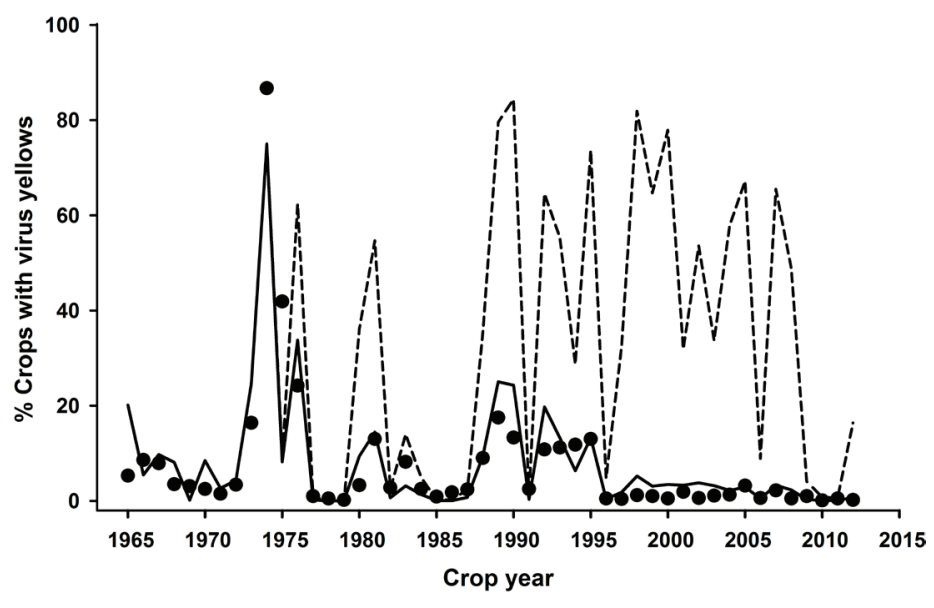

Figure I. Recorded incidences (\% crops affected) of sugar beet crops with virus yellows disease from 1964 to 2012 (๑) in East Anglia, England. These values were compared with the fitted values with parameters that integrated effects of pest management (solid line) such as use of neonicotinoid-pelleted seeds from 1994 onwards while the broken line shows the fitted values without the benefit of pest management.

on crop pathogens and how they will affect yields, profitability and food security under various weather scenarios. Crop management practices such as pest and disease control also influence crop yields by how effectively they protect potential yield as determined by the weather. For example, the widespread use of modern 'stay-green' fungicides has maintained healthier foliage later in the growing season than was normal in the 1990s in English sugar beet crops and has therefore increased yields by at least 5\% (Asher \& Ober, 2005). Furthermore, since 1994 widespread use of neonicotinoid seed treatments has provided excellent control of insecttransmitted virus yellows in the UK sugar beet crop (Figure 1). Without the use of these neonicotinoid insecticides, severe virus yellows epidemics would have occurred in 13 out of the last 20 growing seasons (Qi et al., 2005).

This article focuses on the potential impacts of predicted changes in temperature and rainfall patterns in the UK on two economically important diseases - phoma stem canker (Leptosphaeria spp.) of oilseed rape and powdery mildew (Erysiphe betae) of sugar beet and then discusses how crop protection strategies can be implemented to cope with climate change.

\section{Climate change}

The UK Climate Projections (UKCP09) used outputs from global climate models (Hadley Centre, UK Meteorological Office) and forecast that there will be milder, wetter winters and hotter, drier summers, and more frequent extreme 
Table I. Median estimates of increases in winter and summer mean temperature and of changes in winter and summer mean rainfall for the 2020s, 2050s and 2080s relative to baseline weather from I96I tol990 in the East of England under low, medium and high $\mathrm{CO}_{2}$ emission scenarios (๑ UK Climate Projections 2009).

\begin{tabular}{|c|c|c|c|c|c|}
\hline \multirow{2}{*}{$\begin{array}{l}\mathrm{CO}_{2} \text { emission } \\
\text { scenario }\end{array}$} & \multirow[t]{2}{*}{ Season } & \multirow[t]{2}{*}{ Variable } & \multicolumn{3}{|c|}{ Time period } \\
\hline & & & 2020 s & $2050 s$ & $2080 \mathrm{~s}$ \\
\hline \multirow[t]{4}{*}{ Low } & Winter & $\begin{array}{l}\text { Temperature } \\
\text { increase }\left({ }^{\circ} \mathrm{C}\right)\end{array}$ & 1.3 & 2.0 & 2.6 \\
\hline & & Rainfall change & $+6 \%$ & $+12 \%$ & $+16 \%$ \\
\hline & Summer & $\begin{array}{l}\text { Temperature } \\
\text { increase }\left({ }^{\circ} \mathrm{C}\right)\end{array}$ & 1.5 & 2.4 & 2.7 \\
\hline & & Rainfall change & $-6 \%$ & $-13 \%$ & $-14 \%$ \\
\hline \multirow[t]{4}{*}{ Medium } & Winter & $\begin{array}{l}\text { Temperature } \\
\text { increase }\left({ }^{\circ} \mathrm{C}\right)\end{array}$ & 1.3 & 2.2 & 3.0 \\
\hline & & Rainfall change & $+6 \%$ & $+14 \%$ & $+20 \%$ \\
\hline & Summer & $\begin{array}{l}\text { Temperature } \\
\text { increase }\left({ }^{\circ} \mathrm{C}\right)\end{array}$ & 1.4 & 2.5 & 3.6 \\
\hline & & Rainfall change & $-7 \%$ & $-17 \%$ & $-21 \%$ \\
\hline \multirow[t]{4}{*}{ High } & Winter & $\begin{array}{l}\text { Temperature } \\
\text { increase }\left({ }^{\circ} \mathrm{C}\right)\end{array}$ & 1.3 & 2.5 & 3.7 \\
\hline & & Rainfall change & $+7 \%$ & $+16 \%$ & $+26 \%$ \\
\hline & Summer & $\begin{array}{l}\text { Temperature } \\
\text { increase }\left({ }^{\circ} \mathrm{C}\right)\end{array}$ & 1.4 & 2.9 & 4.5 \\
\hline & & Rainfall change & $-4 \%$ & $-18 \%$ & $-27 \%$ \\
\hline
\end{tabular}

weather events in the UK under all three $\mathrm{CO}_{2}$ emission scenarios (Table 1). These changes indicate increased monthly mean temperature throughout the year and decreased rainfall in summer months. As a result, crop growth stages will occur earlier in the growing season and existing crop diseases will probably change in importance. Future climate change is predicted to be beneficial to crops whose harvestable part is vegetative organs, such as roots of sugar beet (Jaggard et al. 2007). Despite faster development in determinate crops, it is projected that crop yields will increase or stay the same, provided that diseases and pests are still adequately controlled. However, the interactions between crops and pests and pathogens are complex and poorly understood in the context of climate change. Attempting to account for pests and pathogens in crop models would lead to more realistic predictions of future crop production on a regional scale and thereby assist in development of more robust regional food security policies.

\section{Impacts of climate change on crop diseases}

Climate change will have profound impacts on populations of crop pests and pathogens by affecting their survival, reproduction and dispersal, and consequently the resulting crop losses (Figure 2). For example, the damaging sugar beet cyst nematode (Heterodera schachtii) (Figure 2A) will be able



Figure 2. Potential impacts of climate change on arable crop pests and diseases: increased multiplication rate of nematodes $(A)$, establishment of cercospora leaf disease on UK sugar beet (B), increased activity of insect vectors of virus diseases such as green peach-potato aphids for virus yellows in sugar beet (C), increased severity of phoma stem canker (D) due to earlier appearance of phoma leaf spotting $(E)$ in winter oilseed rape, and increased incidence of powdery mildew in sugar beet $(F)$.

to produce six generations per cropping season in warmer conditions in the 2080s instead of three generations under present conditions. Many crop pathogens are favoured by warm, humid conditions. In the UK, there will be increased 
risk of new pests or diseases, such as cercospora leaf spot (Cercospora beticola) (Figure 2B), a destructive leaf disease in sugar beet. In general, warmer conditions throughout the year will exacerbate insect-vectored virus diseases, such as virus yellows transmitted by green peach-potato aphids (Myzus persicae) in sugar beet (Figure 2C). However, the full impact of climate change will depend on the timing of important events in epidemics of each disease and will be both diseasespecific and crop-specific. Phoma stem canker (Leptosphaeria spp.) in winter oilseed rape (Huang et al., 2007) and powdery mildew (Erysiphe betae) in sugar beet (Asher \& Williams, 1991) are discussed below as examples of diseases which have been studied using weather-based disease forecasting models.

\section{Phoma stem canker in oilseed rape}

Previous work concluded that stem canker of oilseed rape (Figure 2D) will be more severe in the spring/summer and the range of the disease will also be increased under climate change in 2020s and 2050s because phoma leaf spotting (Figure 2E) will start to appear earlier in the autumn (Evans et al., 2008; Butterworth et al., 2010). The weather-based ascospore-release model to predict the first date of a major ascospore release by Leptosphaeria spp. (Huang et al., 2007) and 200 years of daily weather generated by the LARS-WG generator (http://www.rothamsted.ac.uk/mas-models/larswg. php) at Rothamsted under a medium $\mathrm{CO}_{2}$ emission scenario were used to assess the impact of climate change on the time of release of the airborne inoculum that infects the oilseed rape leaves (Figure 3). The mean date of first major ascospore release will be considerably earlier from the 2050s onwards. However, the variability in the date of first major ascospore release is predicted to decrease a little in 2080s. This could be a result of consistently warmer temperatures in autumn because the rate of pseudothecial maturity is dependent strongly on temperature.

\section{Powdery mildew in sugar beet}

Powdery mildew (Figure 2F), favoured by warm, dry weather, usually first appears on sugar beet leaves in late summer or early autumn in England. Annual change in the national crop area have been shown to be closely related to the total number of frost days between 1 February and 31 March, the total number of rain days and the mean temperature between 1 April and 31 August (Asher \& Williams, 1991). This weatherbased disease model to predict national sugar beet crop area affected with powdery mildew and 200 years of daily weather generated at Broom's Barn under a medium $\mathrm{CO}_{2}$ emission scenario were used to assess the impact of climate change on the percentage of the sugar beet area affected with powdery mildew (Figure 4). It is predicted that both a decrease in number of frost days and an increase in summer mean air temperature will increase the incidence of powdery mildew on English sugar beet in the future.

Can crop protection cope with climate change? Climate change will produce challenges for crop protection,

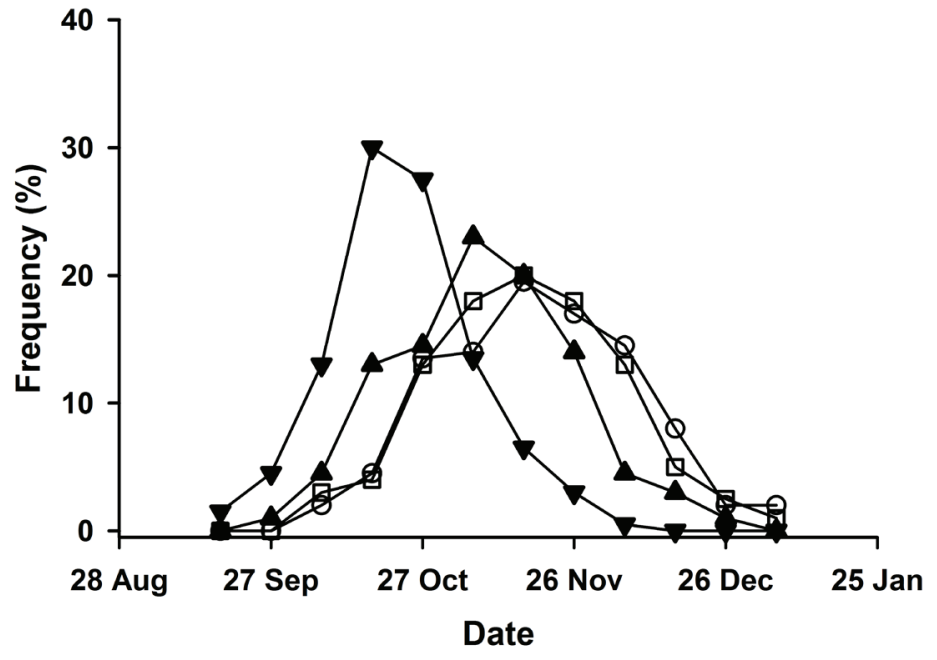

Figure 3. The frequency distribution of the date of first major release of ascospores by Leptosphaeria spp. causing phoma stem canker in oilseed rape for the baseline weather (1975-2005) (O) and the projected weather for 2020s ( $\square$ ), 2050s ( $\mathbf{\Delta})$ and 2080s ( $\boldsymbol{\nabla})$ under a medium $\mathrm{CO}_{2}$ emission scenario at Rothamsted, Hertfordshire, England.



Figure 4. Box-plot showing the proportions (\%) of the UK sugar beet area affected by sugar beet powdery mildew for the 2020s, 2050s and 2080 s under a medium $\mathrm{CO}_{2}$ emission scenario in comparison with the baseline period (1975-2005), estimated using 200 years of daily weather generated for Broom's Barn, Suffolk, England. Each box-plot shows values for the mean (broken line) and the median (solid line) proportions of crops affected by powdery mildew while, respectively, the lower and upper edges of the box are the proportions of crop areas affected for the $25^{\text {th }}$ and $75^{\text {th }}$ percentiles, and the lower and upper bars are for the $5^{\text {th }}$ and 95 th percentiles.

which is expected to play a crucial part not only in sustaining food supply but also in mitigating future climate change through increased crop productivity per unit of inputs such as nitrogen. Milder winters and warmer springs will advance both crop development and disease epidemic progress. Therefore, both the use of pesticides and the optimal timing of sprays will need to change to achieve effective crop protection, 
wdue to likely dyssynchrony between crop and disease development. Since climate change will increase risk of invasion by alien pathogens and pests, it will be important to maintain or increase statutory crop monitoring, quarantine and surveillance. Under climate change, rapid responses to changes in disease risk will become more important as the weather patterns become more uncertain and the impacts of prevailing weather conditions become more difficult to predict. Increased monitoring of the development of disease epidemics by growers, agronomists and expert systems will be required in order to respond to the challenge of managing diseases rapidly and effectively.

Although cultivation of resistant or tolerant crop cultivars and use of cultural practices such as rotation for disease control will remain valuable, the use of pesticides will still be required for protecting crops from pests and diseases for the foreseeable future. For example, even though nematoderesistant sugar beet cultivars are now grown in California, the United States, they can be overwhelmed by nematodes and soil nematicides still have to be used to control those nematodes (Dewar \& Cooke, 2006). However, the efficacy of pesticides may be reduced or nullified by climate change, especially if there are more extreme weather events. For example, drought immediately after sowing crops decreases the effectiveness of seed-borne insecticides because they may not move into soil and be taken up by the seedlings until after the target pests have arrived. Furthermore, increased temperature may decrease effectiveness of crop genes for resistance to some pathogens, such impacts have been observed for some resistance genes operating against the pathogen that causes phoma stem canker in winter oilseed rape (Huang et al. 2006).

For the long-term adaptation to climate change, it is important to ensure that crop germplasm collections are maintained with as much diversity as possible and regularly evaluated so that they can be exploited in future crop improvement programmes. Tactically, early disease inoculum detection and identification and accurate forecasting of the date of arrival of pathogen inoculum are important in both halting epidemics and determining spray timing for optimal control and maximal yield response (West et al., 2009). In addition, more research is needed to assess the impacts of climate change on a wider range of soil-borne and foliar crop diseases in different countries, to guide government and industry strategies for effective responses. For this, there is a need to collate longterm data sets showing how the incidence and severity of epidemics have changed in relation to annual fluctuations in weather conditions. Further research is also needed to help to understand the effects of increased $\mathrm{CO}_{2}$ concentration on plant pathogens since increased atmospheric $\mathrm{CO}_{2}$ will lead to a denser crop canopy which will encourage foliar diseases, in particular.

\section{Concluding remarks}

Pests and diseases cause estimated yield losses of ca. 15\% in world-wide agricultural production, despite current crop protection practices (Oerke, 2006). Climate change, with increasing frequency of extreme weather events, will present new challenges for crop protection to maintain crop health and protect crop productivity. Many assessments of the impact of climate change have been done on the potential growth and yield of the healthy crops, but the impacts on pests and diseases have largely been ignored. Therefore, a 'whole system' approach is required. It must integrate all aspects of crop productivity and management, including climate, crop growth, disease epidemics, insect attack and weed competition into models able to quantify the socio-economic impacts and consequences of adapting crop protection to risks posed by future climate change. Climate change offers opportunities to increase crop productivity and to diversify cropping systems (e.g. sowing sugar beet in autumn and growing new crops such as maize and sunflower in the south of England). However, more robust and integrated crop protection measures are critical not only to maintain a secure food supply, but also to reduce the carbon footprint per unit of production. Thus efficient and effective control of diseases can contribute to climate change mitigation from crop production by decreasing emissions of greenhouse gases (GHG) (Hughes et al., 2011).

\section{References}

Asher, M.J.C. \& Williams, G.E. (1991). Forecasting the national incidence of sugar-beet powdery mildew from weather data in Britain, Plant Pathology, 40: 100-107.

Asher, M. J.C. \& Ober, E. (2005). Fungicides for the control of foliar diseases in sugar beet: fungicidal and physiological effects. In: Aspects of Applied Biology 76, Production and Protection of Sugar Beet and Potatoes, pp. 27-33, Association of Applied Biologists, UK.

Barnes, A.P., Wreford, A., Butterworth, M.H., Semenov, M.A., Moran, D., Evans, N. \& Fitt, B.D.L. (2010). Adaptation to increasing severity of phoma stem canker on winter oilseed rape in the UK under climate change, The Journal of Agricultural Science, 148: 683-694.

Bruinsma, J. (2011). Chapter 6 - The resource outlook to 2050: by how much do land, water use and crop yields need to increase by 2050? In Conforti, P. (ed.) (2011), pp. 233-278, Looking ahead in World Food and Agriculture: Perspectives to 2050, FAO, Rome, (http://www.fao.org/docrep/014/i2280e/i2280e06.pdf).

Butterworth, M.H., Semenov, M.A., Barnes, A., Moran, D., West, J.S. \& Fitt, B.D.L (2010). North-South divide: contrasting impacts of climate change on crop yields in Scotland and England. Journal of the Royal Society Interface, 7: 123-130.

Dewar, A. M. \& Cooke, D. A. (2006). Chapter 13-Pests. In: Sugar Beet (Ed P. Draycott), pp. 316-358: Blackwell Publishing, Oxford.

Evans, N., Baierl, A., Semenov, M.A., Gladders, P. \& Fitt, B.D.L. (2008). Range and severity of a plant disease increased by global warming. Journal of the Royal Society Interface, 5: 525-531.

Jaggard, K. W, Qi, A. \& Semenov, M.A. (2007). The impact of climate change on sugarbeet yield in the UK: 1976-2004. Journal of Agricultural Science 145: 367-375.

Huang, J. J., Evans, N., Li, Z. Q., Eckert, M. Chevre, A. M., Renard, M. \& Fitt, B. D. L. (2006). Temperature and leaf wetness duration affect phenotypic expression of Rlm6-mediated resistance to Leptosphaeria maculans in Brassica napus. New Phytologist, 170: 129-141.

Huang Y.H., Liu Z., West J.S., Todd A.D., Hall A.M. \& Fitt B.D.L. (2007). Effects of temperature and rainfall on date of release of ascospores of Leptosphaeria maculans (phoma stem canker) from winter oilseed rape (Brassica napus) debris in the UK. Annals of Applied Biology, 151: 99-111. 
Hughes D. J., West, J. S., Atkins, S. D., Gladders, P., Jeger, M. J. \& Fitt, B.D. L. (2011). Effects of disease control by fungicides on Greenhouse Gas (GHG) emissions by UK arable crop production. Pest Management Science 67, 1082-1092.

Oerke, E. C. (2006). Crop losses to pests. Journal of Agricultural Science, 144: 31-43.

Qi, A., Dewar, A. M. \& Harrington, R. (2005). Forecasting virus yellows incidence in sugar beet - the post-Gaucho era. In: Aspects of Applied Biology 76, Production and Protection of Sugar Beet and Potatoes, pp. 87-94, Association of Applied Biologists, UK.

Tubiello, F. N., Soussana, J-F. \& Howden, S.M. (2007). Crop and pasture response to climate change. Proceedings of the National Academy of Sciences 104: 19686-19690

West, J.S., Atkins, S.D. \& Fitt, B.D.L. (2009). Detection of airborne plant pathogens; halting epidemics before they start. Outlooks on Pest Management, 20: 11-14

\section{Acknowledgments}

Dr Mikhail Semenov at Rothamsted Research has provided the weather generator to generate daily weather in different time periods under different $\mathrm{CO}_{2}$ emission scenarios in the
UK. The work related to phoma stem canker in oilseed rape received grant-aided support from the UK Biotechnology and Biological Sciences Research Council. Surveys and records of disease data on sugar beet were kindly provided by British Sugar plc. Baseline climate data were from Broom's Barn Research and Rothamsted Research where weather stations were maintained by UK Met Office.

Similar articles that appeared in Outlooks on Pest Management include - 2008 I 9(I) 22; 2012 23(2) 50

\section{Take out a subscription to International Pest Control ... \\ $\ldots$ and get online access to the IPC archives back to January 2004 -- Free!}

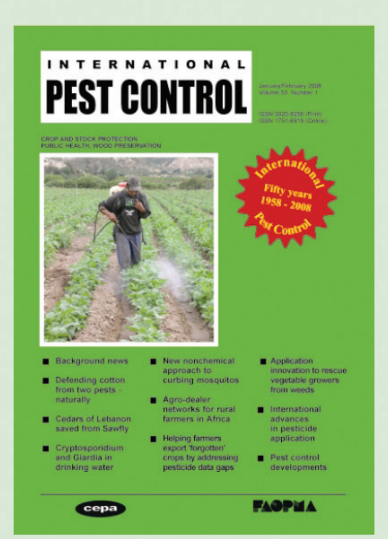

All subscribers have FREE online access to our fully searchable online archives, covering all issues from 2004 to date. The online licence for institutional subscribers covers all users at the subscription address.

All issues are now viewable in Flash-based 'pageflip' format see http://researchinformation.co.uk\#ipco

\section{Complete the form opposite and fax or post back to:}

The Subscription Manager, Research Information Ltd, Grenville Court, Britwell Road, Burnham, Bucks. SL1 8DF, UK.

Tel: $+44(0) 1628600499$ Fax: $+44(0) 1628600488$

Email: info@researchinformation.co.uk

Web: www.researchinformation.co.uk

\section{Subscription Order Form}

Please send me International Pest Control (six issues) for one year @

[ ] $£ 156$ (US\$312) Institutional

[ ] $£ 85$ (US\$170) Personal

[ ] $£ 60$ (US\$120) CEPA/FAOPMA Member

Name / Job title:

Dept:

Organisation:

Address:

Postcode:

Email:

[ ] Please send a proforma invoice

[ ] I enclose a cheque drawn on a UK bank

Please charge my:

[ ] Mastercard [ ] Visa [ ]Amex

Card no:

Expiry date: Security (CVV) digits:

Name on card

Signature: 